\title{
Founder team interaction, customer and competitor orientation in software ventures
}

Founder team interaction

\author{
Thilo A. Mueller \\ Berlin University of Technology, Stuttgart, Germany, and \\ Hans Georg Gemünden \\ Berlin University of Technology, Berlin, Germany
}

\begin{abstract}
Purpose - Developments in the software industry have shown the need for sustainable and effective management strategies, especially for new ventures. Entrepreneurship literature suggests marketing to be one of the pivotal predictors of business performance. Previous empirical studies have shown the importance of social interaction and team work quality for new venture performance. The purpose of this paper is to apply founder team interaction quality (IQ), and the customer and competitor orientation concept of marketing research to new software venture performance.

Design/methodology/approach - An empirical study using a fully standardized questionnaire was conducted in 101 young software ventures. Two founders in each company filled out the questionnaire separately allowing superior tests for reliability and validity of the research framework. Findings - The results show team IQ to be a powerful predictor of both customer orientation and competitor orientation. Furthermore, a positive, linear relationship between competitor orientation and technological performance has been found. There is a curvilinear U-shaped relationship between customer orientation and all examined success dimensions, i.e. economic, market and technological success.

Originality/value - Based on a theoretical research framework and a comprehensive empirical study, the paper contributes to a limited body of research and provides insight for managers of young ventures in the nature of teamwork and IQ and its effects on market orientation and company performance.
\end{abstract}

Keywords Teams, Social interaction, Computer software, Customer orientation, Competitors

Paper type Research paper

\section{Introduction}

During the past decade, managers and researchers have identified the importance of market and customer orientation for sustainable competitive advantage and superior company performance. The empirical research on market orientation is based mainly on the studies of Narver and Slater (1990) and Jaworski and Kohli (1993). Although a great deal of marketing research has investigated market orientation (e.g. Greenley, 1995; Appiah-Adu, 1997; Kumar et al., 1998), and especially customer and competitor orientation (e.g. Pelham and Wilson, 1996; Balakrishnan, 1996), the role of these aspects for new venture management is still unclear, particularly in the context of dynamic markets such as software industry.

Although the development of information and communication technology industries has slowed down, compared to the strong growth at beginning of the twenty-first century, software products are still expected to achieve high annual growth rates. Due to this dynamic development business opportunities are generated continuously for new software ventures, which often operate with higher flexibility than their established larger competitors.

In many cases, these ventures have multiple founders who are mainly computer scientists and programmers. For this reason, product development and technological

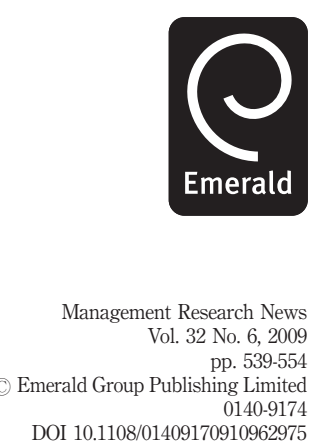


MRN

32,6

540 issues receive major attention in the early stages of software venture development on the one hand. On the other hand, a lack of business management and marketing skills may result in an underestimation of market knowledge for venture success. Researchers in various studies on young technology companies have claimed marketing and market knowledge to be one of the pivotal factors influencing failure or success of these ventures (e.g. Keh et al., 2007; Hills and Star, 1985; Slevin and Covin, 1987). Therefore, we seek to shed some light on the effects of customer and competitor knowledge on software venture performance. As software ventures are usually founded by two or more persons we will examine the role of founder interaction.

The paper is organized as follows: First, we will discuss the theoretical foundations of our research framework, i.e. the constructs interaction quality, and customer and competitor orientation. Second, we will develop and explain the central hypotheses of the investigation. The third section is dedicated to details of data collection, the method and the outcomes of our empirical study. At the end of this article, we discuss limitations of our study as well as theoretical and managerial implications in this field.

\section{Theoretical foundations}

While the different frameworks for the examination of market orientation include customer orientation implicitly (Jaworski and Kohli, 1993) or explicitly (Narver and Slater, 1990; Ruekert, 1992), a stream of research that focuses on customer orientation and competitor orientation separately has shown mixed results for their effect on company performance (Appiah-Adu and Singh, 1998; Li and Calantone, 1998). Further on, Greenley (1995) has used Narver and Slater's framework in a study of market orientation in British industrial companies, which led to a partial rejection of performance hypotheses. As industry and country characteristics may influence the understanding and the effect of market orientation, there is a necessity to conduct a study which is industry specific in order to get results which can be interpreted clearly and without ambiguity although this design limits the possibility of general statements.

In the following paragraphs, we discuss the theoretical aspects and results of empirical studies on the three main constructs of our analysis: Interaction quality (IQ) of the founders, customer orientation and competitor orientation founders. The objective is to develop a definition for each construct considering the focus on new software ventures in this study.

\section{IQ of the founders}

A growing body of research emphasizes the role of founder team interaction in new business development (Kamm et al., 1990; Ensley and Amason, 1999; Mellewigt and Späth, 2001; Taulicar et al., 2005). Watson et al. (1995) describe the venture team interpersonal process with the four dimensions leadership, interpersonal flexibility, team commitment and helpfulness. The results of their empirical study indicate the importance of team leadership and commitment for perceived venture success. Lechler and Gemuenden (1999) found six dimensions of social interaction within entrepreneurial teams to be good predictors of technology venture success: communication, cohesion, work norms, mutual support, coordination and conflict resolution. Communication is a basic part of teamwork as it serves for information exchange (Pinto and Pinto, 1990). Intensity and the degree to which team members 
communicate frankly with each other describe the quality of communication (Helfert and Gemuenden, 2001; Gladstein, 1984). Software development, in particular, is characterized by a need to coordinate the work of individuals on day-to-day bases (Sheremata, 2002, p. 146). Coordination is especially important for task fulfilment in software venture teams. Tjosvold (1995) emphasizes the role of mutual support among team members for successful teamwork. Based on cooperation rather than competition, team members achieve a higher level for integration of their individual interests, and therefore accomplish jointly the goals of the venture team.

Hence, we define IQ of the founder team in new software ventures as follows:

The IQ of the founder team is defined as the level to which founders communicate intensively and frankly, and the level of mutual support, cooperation and coordination.

\section{Customer orientation}

Researchers mention the "call for customer orientation [. . . ] as the focus for all business planning and strategy" (Deshpandé et al., 1993, p. 23). Despite the differences in conceptualization, gathering information on customers, meeting their needs and creating value for them (Lafferty and Hult, 2001) are essential ingredients for a customer oriented business. Customer orientation refers to a company's understanding of its buyers to be able to continuously create value for them (Narver and Slater, 1990). Value from a customer's point of view can be understood as the trade-off between benefits and sacrifices in buyer-supplier relationships (Zeithaml, 1998). "Customer orientation requires that a seller understands a buyer's entire value chain, not only as it is today but also as it will evolve over time subject to internal and market dynamics" (Narver and Slater, 1990, p. 21). The concept of customer orientation includes understanding customers' needs and satisfying them, as well as perceiving and reducing his perceived sacrifices. In their study on small business' customer orientation and performance Appiah-Adu and Singh (1998, p. 386) define customer orientation as "the organization-wide emphasis on evaluating and addressing customer needs". Consequently, a customer-oriented company has to establish continuous communication with its actual and potential customers and create a customer-focused environment within a company (Hartline et al., 2000). Besides the two aspects concerning information on customer needs and requirements, and on customer satisfaction, the integration of customers in product development has to be considered as a third facet of customer orientation in software ventures.

Along with the previous considerations, we define customer orientation of new software ventures as a business process comprehending the management of information on customers' needs, wishes and requirements, information on customer satisfaction and the management of customer integration in product development.

\section{Competitor orientation}

Marketing researchers regard competitor orientation as an important part of market orientation (e.g. Han et al., 1998; Gray et al., 1998). Competitor orientation comes along with an organization's broader understanding of market operating characteristics. An exclusive customer focus may result in incomplete business strategy and action (Han et al., 1998). Day and Wensley (1988) suggest a balance of an organization's customer and competitor focus. We believe competitor orientation to entail sourcing information on competitors, competitors' activities and offerings, and market potentials. Along with Narver and Slater (1990) competitor orientation can be understood as company

Founder team interaction 
MRN

32,6

understandings of strengths, weaknesses, capabilities and strategies of key and key potential competitors.

Competitor orientation of new software ventures is defined as a business process, comprehending the management of information on actual and potential competitors' companies, activities and products.

\section{2}

\section{Hypotheses and theoretical framework}

\section{$I Q$ of the founders and customer and competitor orientation}

We have defined customer orientation and competitor orientation as business processes, concerning the management of information on customers and competitors and customer integration. The management of information on markets refers to the generation and especially the dissemination of information within a company (Jaworski and Kohli, 1993). Day (1994, p. 45) argues, that "suppliers must be prepared to develop team-based mechanisms for continuously exchanging information about needs, problems and emerging requirements and then taking action". The capacity of information processing in the company depends on the IQ of the founder management team.

Hence, we propose the following:

H1. The better the founders in a software venture interact with each other, the higher customer orientation of this software venture.

H2. The better the founders in a software venture interact with each other, the higher competitor orientation of this software venture.

Customer orientation and performance

Customer orientation is one of the pivotal aspects of business management for delivering superior value to customers (Narver and Slater, 1990, p. 21). Efficient product development and innovation (Salomo, 2003), effective marketing activities and especially an increased willingness of customers to accept higher process for products (Homburg and Werner, 1998) with high customer value are the outcomes of consequently implemented customer orientation.

Knowledge of customers' needs and requirements allows software ventures to approach the group of customers with their technological solution and offers the most suitable products (Walsh and Kichhoff, 2001). Customer orientation provides a basis for precise customer acquisition and market action. Additionally, customer integration and information on customer satisfaction will enhance customer relationship development and improve customer retention.

In software development meeting time and/or quality goals constitute major problems (Sheremata, 2002). In young and small companies achieving customer and market orientation is challenging (Golann, 2006). As product life cycles are very short, software companies struggle to provide new high quality products with increasing frequency. Continuous and prompt feedback of customers will allow software ventures to consider technological requirement on time and improve technological quality and development of software products.

Hence, we introduce the following hypothesis:

H3. The higher the customer orientation of young software ventures the greater (a) economic, (b) market and (c) technological success. 


\section{Competitor orientation and performance}

Balakrishnan (1996) has found companies with a high competitor orientation to have a better understanding for the value of products and services on the market. Based on information on competitors' products, software ventures are able to develop successful strategies for product positioning on their markets, which leads to better sales and a positive economic development. The knowledge about strengths and weaknesses of competitors enable companies to identify and occupy profitable market positions and market niches (Day and Wensley, 1988). New ventures are often founded as a result of a gap in the market the founders have discovered as a business opportunity. In order to preserve competitive advantages after the foundation, and to reach a favourable market and technological position, it is essential to carefully watch competitors' moves and products. "A firm with more competitive information is able to use its knowledge in several ways, including its strengths against a competitor's weakness, internalising a competitor's strength by imitation, or nullifying a competitor's strength by product differentiation" (Li and Calantone, 1998, p. 17). Thus, we hypothesize:

H4. The higher competitor orientation of young software ventures the greater (a) economic, (b) market and (c) technological success.

\section{Curvilinear effects of customer orientation and competitor orientation}

We have mainly theorized linear relationships between customer orientation, competitor orientation and performance. These two aspects of marketing management have both positive and negative effects on performance. Negative effects emerge from financial, personnel and technological resources which have to be deployed, we argue that linear relationships in the sense of "the higher ... the more" might be too simple. These thoughts are supported by the results of previous studies that found U-shaped, curvilinear relationships of market orientation and profitability of strategic business units (Narver and Slater, 1990). Especially, young technology ventures have to carefully consider which activities they wish to invest their scarce resources. We assume that the negative effects caused by resource consumption exceed the positive effects of low to medium level customer and competitor orientation. Not until customer and competitor orientation become fully implemented in new venture management will positive effects outgain the negative aspects. Therefore, we presume the following hypotheses on a U-shaped relationship, and compete with the previously stated $H 3$ and $H 4$ on a linear relationship:

H5. There is a curvilinear, U-shaped relationship between customer orientation and (a) economic, (b) market and (c) technological success. The relationship is negative at low levels of customer orientation and becomes positive at higher levels.

H6. There is a curvilinear, U-shaped relationship between competitor orientation and (a) economic, (b) market and (c) technological success. The relationship is negative at low levels of competitor orientation and becomes positive at higher levels.

Furthermore, we will test for the moderating effects of the market environment, i.e. competitive intensity and market dynamism, on the above hypothesized relationships.

Founder team interaction

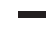


MRN

32,6

544

\section{Method and results}

\section{Data collection}

The level of analysis of this study is limited to new software ventures, which should have a maximum age of seven years. We take a look at the customer orientation and competitor orientation - performance link from the software producer's perspective. The sample we use for data analysis consists of 101 software ventures which were created by two or more founders. We developed a five-page standardized questionnaire reflecting the research questions which was to be completed by two founder-managers of each company.

A random sample of 600 companies was drawn from a database of the Centre for European Economic Research (ZEW) and the Consortium of German Technology and Business Formation Centres (ADT). Initially, the informants were contacted by telephone. We ensured that the companies operated in software business, had an age of one to seven years, and that informants were founder-managers. In a second step, an appointment for a personal interview was scheduled. A total of 150 software ventures agreed to take part in the study. Finally, we obtained 202 usable questionnaires from 101 software ventures, which correspond to an effective response rate of 16.8 per cent. This response rate is moderate, but satisfying due to the difficulty to get the approval for an interview with two founder-managers of the same company.

The companies came from various segments of the IT software market: 37.6 per cent were internet related businesses (e.g. websites, security, intranet, eCommerce solutions), 24.8 per cent developed software for industrial customers (e.g. automation, measurement engineering), 10.9 per cent developed software for databases and networks and 26.7 per cent developed individual company software solutions. The average age of the software ventures was 34 years, so we were able to generate a sample of rather young companies compared to similar studies. The average number of fulltime employees including the founders was 9.5 and the estimated revenue in the year of the survey (2000/2001) was 1.66 million Euros.

We obtained data from the senior and the junior founder in each company, in order to provide extended possibilities for the examination of reliability and validity. The junior founders had an average age of 29 years while the senior founders were on average 34 years old. We considered software ventures in the entire territory of the Federal Republic of Germany.

\section{Measures}

In order to assure validity and reliability of the measures and the statistical model which is based on a theoretical framework, we have chosen an empirical research design with multiple and qualified informants, as the evaluations of separate and equally qualified informants can be used to compare and validate the measures. We conducted independent interviews with two founders in each company.

All constructs were measured using seven point multiple-item scales. The final model includes 27 measures and six constructs. We used traditional and advanced psychometric approaches to evaluate scale properties. Assessing their reliability and uni-dimensionality purified the proposed reflective measures. Measurement development followed procedures recommended in marketing research literature (Anderson and Gerbing, 1988; Homburg and Baumgartner, 1995). First, item-to-total correlation was examined in each of the proposed scales and items with low correlation were deleted if they tapped no additional domain of interest. To help ensure 
uni-dimensionality, items in each multi-item scale were factor analysed separately. In all cases a single factor emerged.

As a first step towards the measurement of the IQ of the founders we reviewed previous studies on entrepreneurial and top management teams (e.g. Hackman, 1987; Hoegl and Gemuenden, 2001; Watson et al., 1995; Ensley and Amason, 1991; Lechler and Gemuenden, 1999). Finally, IQ of the founders was measured with a six-item scale. Employing a principal components factor analysis one factor emerged for the junior (Expl.Var. 69.4 per cent, $\alpha=0.90$ ) and senior founder (Expl.Var. 71.6 per cent, $\alpha=0.91)$.

Customer orientation was measured by three items. The items reflect the above discussed facets of software ventures' customer orientation: information on customer requirements, information on customer satisfaction and customer integration. The items are adapted from the scales used by Li and Calantone (1998), Pelham (1997), and Narver and Slater (1990). Principal components factor analysis resulted in a single factor (Junior: Expl.Var. 61.5 per cent, $\alpha=0.67$; Senior: Expl.Var. 63.2 per cent, $\alpha=0.71$ ).

Competitor orientation was measured using a-item scale. The items were adapted form Narvers and Slater (1990), Pelham (1997) and Jaworski and Kohli (1993). Once again, principal components factor analysis resulted in a single factor (Junior: Expl.Var. 65.1 per cent, $\alpha=0.73$; Senior: Expl.Var. 69.6 per cent, $\alpha=0.78$ ).

Competitive intensity and market dynamism were measured by three items and five items, respectively. The choice of indicators is based on previous empirical research (Lusch and Laczniak, 1987; Jaworski and Kohli, 1993; Pelham and Wilson, 1996). Factor analysis for competitive intensity (Junior: Expl.Var. 67.1 per cent, $\alpha=0.75$; Senior: Expl.Var. 71.9 per cent, $\alpha=0.80$ ) and market dynamism (Junior: Expl.Var. 53.4 per cent, $\alpha=0.78$; Senior: Expl.Var. 48.9 per cent, $\alpha=0.73$ ) resulted in a single factor for each construct.

For performance measurement in management and marketing research objective and subjective measures can be used. Objective measures refer to quantitative data on revenue, profit and growth as well as relative measures such as ROI and ROA. Subjective measures refer to informants' individual evaluations of performance aspects such as satisfaction with financial, market and technological success. In our study of very young software ventures, we found it difficult to obtain objective performance measures. A similar limitation occurs in Pelham's market orientation study (Pelham, 1997 p. 283): "Since most firms sampled were privately held, subjective measures of performance were used due to reluctance of private firm managers to divulge information considered confidential". As subjective and objective performance measures use to correlate highly (Dawes, 1999), we chose subjective measures for our research design.

Economic success of software ventures was measured by five items. These are based on the studies of Pelham (1997) and Narver and Slater (1990), and reflect the five aspects liquidity, speed to first realized profit, profit contribution of products, cost and time efficiency and general financial success. Employing a principal components factor analysis one factor emerged for the junior (Expl.Var. 52.11 per cent, $\alpha=0.74$ ) and the senior founder (Expl.Var. 57.86 per cent, $\alpha=0.81$ ).

Market success. This was measured by three items describing the dimensions competitive position, market recognition and overall market success. Factor analysis showed one factor with satisfying parameters for reliability and validity (Junior: Expl.Var. 69.1 per cent, $\alpha=0.77$, Senior: Expl.Var. 74.19 per cent, $\alpha=0.82$ ).

Three items were used for the measurement of technological success of young software ventures. The items reflect the aspects product development, degree of innovativeness and technologically competitive position. The results of factor analysis

Founder team interaction 
MRN

32,6 are satisfying (Junior: Expl.Var. 71.51 per cent, $\alpha=0.79$, Senior: Expl.Var. 73.10 per cent, $\alpha=0.81$ ).

Confirmatory factor analysis was then conducted using LISREL 8 ( Jöreskog and Sörbom, 1996) with covariance matrix as the input. Table I contains standardized ML parameter estimates for the measurement model, proportions of variance extracted,

\section{6}

\begin{tabular}{|c|c|c|c|c|c|c|c|c|}
\hline \multirow[b]{2}{*}{ Factor/item } & \multicolumn{2}{|c|}{$\begin{array}{l}\text { Indicator } \\
\text { reliability }\end{array}$} & \multicolumn{2}{|c|}{$\begin{array}{l}\text { Average } \\
\text { variance } \\
\text { extracted }\end{array}$} & \multicolumn{2}{|c|}{$\begin{array}{l}\text { Factor } \\
\text { reliability }\end{array}$} & \multicolumn{2}{|c|}{$\begin{array}{l}\text { Cronbach's } \\
\text { alpha }\end{array}$} \\
\hline & Junior & Senior & Junior & Senior & Junior & Senior & Junior & Senior \\
\hline \multicolumn{9}{|c|}{ Interaction quality } \\
\hline Intqual1 & 0.55 & $0.76^{*}$ & & & & & & \\
\hline Intqual2 & $0.71^{*}$ & $0.59 *$ & & & & & & \\
\hline Intqual3 & $0.45^{*}$ & $0.53^{*}$ & & & & & & \\
\hline Intqual4 & $0.46^{*}$ & $0.58^{*}$ & & & & & & \\
\hline Intqual5 & $0.83^{*}$ & $0.71 *$ & & & & & & \\
\hline Intqual6 & 0.83 & $0.81 *$ & 0.64 & 0.66 & 0.91 & 0.92 & 0.90 & 0.91 \\
\hline \multicolumn{9}{|c|}{ Customer orientation } \\
\hline Custor1 & $0.59 *$ & $0.28^{*}$ & & & & & & \\
\hline Custor2 & $0.49^{*}$ & $0.77^{*}$ & & & & & & \\
\hline Custor3 & $0.23^{*}$ & $0.38^{*}$ & 0.44 & 0.48 & 0.69 & 0.72 & 0.67 & 0.71 \\
\hline \multicolumn{9}{|c|}{ Competitor orientation } \\
\hline Compor1 & $0.53^{*}$ & $0.55^{*}$ & & & & & & \\
\hline Compor2 & $0.82^{*}$ & $0.85^{*}$ & & & & & & \\
\hline Compor3 & $0.21 *$ & $0.31^{*}$ & 0.52 & 0.57 & 0.75 & 0.79 & 0.73 & 0.78 \\
\hline \multicolumn{9}{|c|}{ Competitive intensity } \\
\hline Compint1 & $0.49 *$ & $0.58^{*}$ & & & & & & \\
\hline Compint2 & $0.61 *$ & $0.76^{*}$ & & & & & & \\
\hline Compint3 & $0.44^{*}$ & $0.42^{*}$ & 0.51 & 0.59 & 0.75 & 0.81 & 0.75 & 0.80 \\
\hline \multicolumn{9}{|c|}{ Market dynamism } \\
\hline Madyn1 & $0.34^{*}$ & $0.32 *$ & & & & & & \\
\hline Madyn2 & $0.55^{*}$ & $0.21 *$ & & & & & & \\
\hline Madyn3 & $0.41 *$ & $0.36^{*}$ & & & & & & \\
\hline Madyn4 & $0.31^{*}$ & $0.53 *$ & & & & & & \\
\hline Madyn5 & $0.52^{*}$ & $0.40^{*}$ & 0.37 & 0.48 & 0.78 & 0.74 & 0.78 & 0.73 \\
\hline \multicolumn{9}{|c|}{ Economic success } \\
\hline SEco1 & $0.27^{*}$ & $0.36^{*}$ & & & & & & \\
\hline SEco2 & $0.79 *$ & $0.77^{*}$ & & & & & & \\
\hline SEco3 & $0.32 *$ & $0.42 *$ & & & & & & \\
\hline SEco4 & $0.37 *$ & $0.44^{*}$ & & & & & & \\
\hline SEco5 & $0.33^{*}$ & $0.41^{*}$ & 0.42 & 0.48 & 0.78 & 0.82 & 0.74 & 0.81 \\
\hline \multicolumn{9}{|c|}{ Market success } \\
\hline SMark1 & $0.89 *$ & $0.64^{*}$ & & & & & & \\
\hline SMark2 & $0.59 *$ & $0.66^{*}$ & & & & & & \\
\hline SMark3 & $0.36^{*}$ & $0.53^{*}$ & 0.55 & 0.61 & 0.78 & 0.83 & 0.77 & 0.82 \\
\hline \multicolumn{9}{|c|}{ Technological success } \\
\hline STech1 & $0.35 *$ & $0.37 *$ & & & & & & \\
\hline STech2 & $0.67 *$ & $0.76^{*}$ & & & & & & \\
\hline STech3 & $0.76^{*}$ & $0.71^{*}$ & 0.59 & 0.61 & 0.81 & 0.82 & 0.79 & 0.81 \\
\hline
\end{tabular}

\section{Table I.}

Confirmatory factor analysis results 
factor reliability values and Cronbach's Alphas. All items exhibit reasonably high reliabilities. All but one Cronbach's Alpha exceed the threshold value of 0.7 . The average variance extracted except one and all of the construct reliabilities exceed the threshold values of 0.4 and 0.7, respectively (Fornell and Larcker, 1981). Support for discriminant validity was provided by a series of model estimations in which the individual factor correlation was constrained to unity one at a time (Bagozzi et al., 1991). The conducted chi-square difference tests were all significant $(p<0.01)$.

Finally, construct validity for the model of eight constructs was tested with the CFA-approach to develop a Multitrait-Multimethod-Matrix (MTMM) (Bagozzi and Yi, 1991; Bagozzi, 1994a). The results of the MTMM-Analysis $\left(\chi^{2}(60)=111\right.$, RMSEA $=0.065, \mathrm{GFI}=0.935, \mathrm{AGFI}=0.853, \mathrm{CFI}=0.947)$ allowed a choice of the constructs which were measured with highest validity.

Results of regression analysis

The results of the hierarchical multiple regression for customer orientation and competitor orientation (Tables II and III) reveal a strong and highly significant influence of IQ of the founders on both constructs. Even though the effect on competitor orientation $(\beta=0.24, p<0.05)$ is lower than it is on customer orientation $(\beta=0.50, p<0.01), H 1$ and $H 2$ are supported.

The moderated hierarchical multiple regression analysis (Cortina 1993) for economic success reveals three interesting results (Table IV). First, there is no linear relationship between customer and competitor orientation, and economic success.

$H 3 a$ and $4 a$ are rejected. Second, there is a curvilinear U-shaped relationship between customer orientation and economic success $(\beta=0.21, p<0.05)$. Figure 1 shows the quadratic curve fitting of customer orientation and success measures this conclusion is based on. $H 5 a$ is supported, whereas $H 6 a$ is rejected. Third, there is a strong moderating effect of market dynamism on the customer orientation - economic success - relationship. A graphical analysis shows that the relevance of customer orientation for economic success is greater with increasing market dynamism. This effect comes along with a significant change in $R^{2}\left(\Delta R^{2}=8.7\right.$ per cent, $\left.p<0.1\right)$.

\begin{tabular}{lccc}
\hline Indepedent variables & Model 1 & Model 2 & Model 3 \\
\hline Main effects & & & \\
IQ of the founders & & $0.46^{* * * *}$ & $0.50^{* * * *}$ \\
Interaction effects & & & \\
IQ * Competitive intensity & & & -0.66 \\
IQ ${ }^{*}$ Market dynamism & & & 0.11 \\
Control variables & -0.08 & -0.05 & -0.02 \\
Competitive intensity & -0.12 & $-0.21^{* *}$ & $-0.22^{* *}$ \\
Market dynamism & -0.04 & -0.01 & -0.03 \\
Venture age & $0.15^{*}$ & $0.23^{* *}$ & $0.23^{* * *}$ \\
Venture size & 5.1 & 25 & 26.2 \\
$R^{2}(\%)$ & $\Delta 5.1$ & $\Delta 19.9^{* *}$ & $\Delta .2$ \\
$\Delta R^{2}(\%)$ & 1.29 & $6.33^{* * *}$ & $4.72^{*}$ \\
$F$ & 101 & 101 & 101
\end{tabular}

Notes: * Significant at 10 percent; ** significant at 5 percent; *** significant at 1 percent (one sided)
Founder team interaction , 


\section{MRN \\ 32,6}

548

Regression analysis, competitor orientation

\begin{tabular}{lccc}
\hline Indepedent variables & Model 1 & Model 2 & Model 3 \\
\hline Main effects & & & \\
IQ of the founders & & $0.27^{* * *}$ & $0.24^{* *}$ \\
Interaction effects & & \\
IQ * Competitive intensity & & & $-0.66^{*}$ \\
IQ * Market dynamism & & & $0.16^{*}$ \\
Control variables & & -0.11 & \\
Competitive intensity & -0.13 & 0.14 & -0.07 \\
Market dynamism & $-0.19^{* * *}$ & 0.06 & $0.13^{*}$ \\
Venture age & 0.04 & -0.05 & 0.07 \\
Venture size & -0.09 & 11.7 & 0.03 \\
$R^{2}(\%)$ & 5.1 & $\Delta 6.7^{* * * *}$ & 16.4 \\
$\Delta R^{2}(\%)$ & $\Delta 5.1$ & $2.53^{* *}$ & $\Delta 4.6^{*}$ \\
$F$ & 1.29 & 101 & $2.60^{* *}$ \\
$N$ & 101 & & 101
\end{tabular}

Notes: * Significant at percent; ** significant at 5 percent; *** significant at 1 percent (one sided)
Table IV.

Regression analysis, economic success

\begin{tabular}{|c|c|c|c|c|}
\hline Indepedent variables & Model 1 & Model 2 & Model 3 & Model 4 \\
\hline \multicolumn{5}{|l|}{ Main effects } \\
\hline Customer orientation (CS) & & 0.02 & -0.10 & -0.02 \\
\hline Competitor orientation (CM) & & -0.09 & -0.03 & 0.00 \\
\hline \multicolumn{5}{|l|}{ Interaction effects } \\
\hline CS * Competitive intensity & & & -0.110 & -0.09 \\
\hline CS * Market dynamism & & & $0.34^{* * * *}$ & $0.39 * * *$ \\
\hline $\mathrm{CM} *$ Competitive intensity & & & -0.10 & -0.09 \\
\hline CM * Market dynamism & & & 0.00 & 0.01 \\
\hline \multicolumn{5}{|l|}{ Curvilinear effects } \\
\hline $\mathrm{CS} * \mathrm{CS}$ & & & & $0.21 * *$ \\
\hline $\mathrm{CM} * \mathrm{CM}$ & & & & 0.00 \\
\hline \multicolumn{5}{|l|}{ Control variables } \\
\hline Competitive intensity & $-0.14^{*}$ & $-0.14^{*}$ & -0.02 & -0.01 \\
\hline Market dynamism & 0.01 & 0.03 & -0.12 & -0.13 \\
\hline Venture age & 0.13 & 0.12 & $0.16^{*}$ & $0.17^{*}$ \\
\hline Venture size & $0.16^{*}$ & $0.17 *$ & $0.14^{*}$ & 0.11 \\
\hline IQ of the founders & $0.16^{*}$ & $0.18^{*}$ & $0.23 * *$ & $0.20 * *$ \\
\hline$R^{2}(\%)$ & 8.5 & 9.2 & & \\
\hline$\Delta R^{2}(\%)$ & $\Delta 8.5$ & $\Delta 0.7$ & $\Delta 8.7^{*}$ & $\Delta 3.1$ \\
\hline$F$ & 1.78 & 1.35 & $1.77^{*}$ & $1.78^{*}$ \\
\hline$N$ & 101 & 101 & 101 & 101 \\
\hline
\end{tabular}

Notes: * Significant at 10 percent; ** significant at 5 percent; $* * *$ significant at 1 percent (one sided)

The results of regression analysis on market success (Table V) show similarities to the above discussed results for economic success. Once again $H 3 b$ and $H 4 b$ about linear effects of customer orientation and competitor orientation are rejected, but there is a significant curvilinear, U-shaped effect of customer orientation on market success 


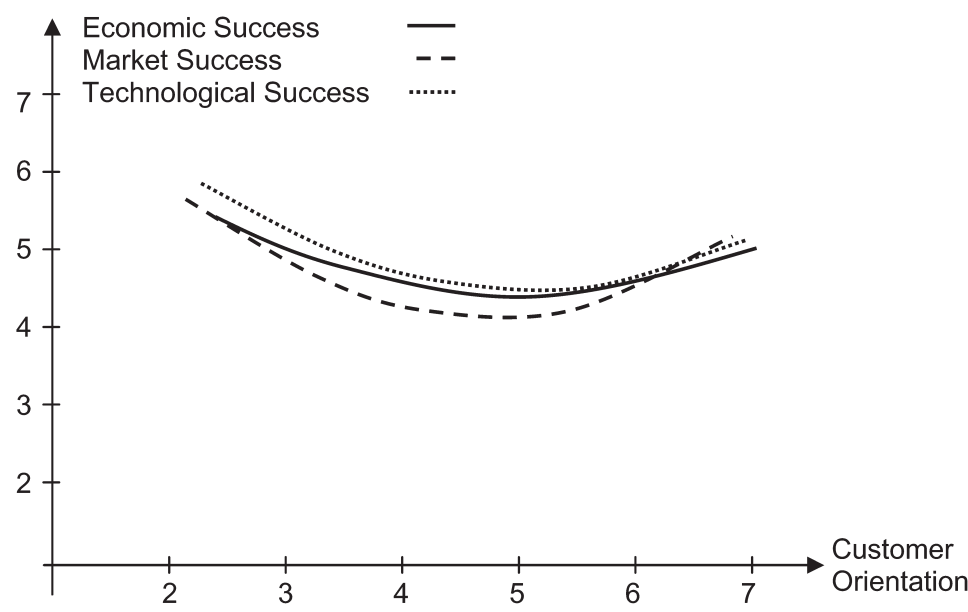

\section{Founder team interaction}

Figure 1. Curve fitting (quadratic) for customer orientation

\begin{tabular}{|c|c|c|c|c|}
\hline Indepedent variables & Model 1 & Model 2 & Model 3 & Model 4 \\
\hline \multicolumn{5}{|l|}{ Main effects } \\
\hline Customer orientation (CS) & & 0.08 & 0.05 & 0.15 \\
\hline Competitor orientation (CM) & & 0.04 & 0.06 & 0.09 \\
\hline \multicolumn{5}{|l|}{ Interaction effects } \\
\hline CS * Competitive intensity & & & -0.09 & -0.07 \\
\hline CS * Market dynamism & & & 0.04 & 0.10 \\
\hline $\mathrm{CM} *$ Competitive intensity & & & -0.07 & -0.07 \\
\hline CM * Market dynamism & & & 0.08 & 0.11 \\
\hline \multicolumn{5}{|l|}{ Curvilinear effects } \\
\hline $\mathrm{CS} * \mathrm{CS}$ & & & & $0.27 * *$ \\
\hline $\mathrm{CM} * \mathrm{CM}$ & & & & -0.06 \\
\hline \multicolumn{5}{|l|}{ Control variables } \\
\hline Competitive intensity & $-0.21 * *$ & $-0.20 * *$ & $-0.15^{*}$ & -0.13 \\
\hline Market dynamism & 0.09 & 0.10 & 0.05 & 0.03 \\
\hline Venture age & $0.21 * *$ & $0.19 * *$ & $0.21 * *$ & $0.22 * *$ \\
\hline Venture size & $0.35^{* * * *}$ & $0.35^{* * * *}$ & $0.33^{* * * *}$ & $0.29^{* * * *}$ \\
\hline IQ of the founders & $0.16^{* *}$ & 0.11 & 0.13 & 0.10 \\
\hline$R^{2}(\%)$ & 26.1 & 26.9 & 28.4 & 32.8 \\
\hline$\Delta R^{2}(\%)$ & $\Delta 26.1 * * *$ & $\Delta 0.7$ & $\Delta 1.6$ & $\Delta 4.3^{*}$ \\
\hline$F$ & $6.72^{* * * *}$ & $4.88 * * *$ & 3.21 *** & 3.26 **** \\
\hline$N$ & 101 & 101 & 101 & 101 \\
\hline
\end{tabular}

Notes: * Significant at 10 percent; ** significant at 5 percent; *** significant at 1 percent (one sided)

Table V. Regression analysis, market success

$(\beta=0.27, p<0.05)$ which is associated with a significant change in $R^{2}\left(\Delta R^{2}=4.3\right.$ per cent, $p<0.1$ ). We can support $H 5 b$ (H6b rejected).

Finally, regression analysis (Table VI) reveals a significant linear relationship between competitor orientation and technological success $(\beta=0.29, p<0.01, H 4 c$ 


\begin{tabular}{|c|c|c|c|c|c|}
\hline \multirow{5}{*}{$\begin{array}{l}\text { MRN } \\
32,6\end{array}$} & \\
\hline & Indepedent variables & Model 1 & Model 2 & Model 3 & Model 4 \\
\hline & Main effects & & & & \\
\hline & Customer orientation (CS) & & -0.09 & -0.11 & -0.03 \\
\hline & Competitor orientation (CM) & & $0.25^{* * * *}$ & $0.26^{* * * *}$ & $0.29 * * *$ \\
\hline \multirow{16}{*}{550} & Interaction effects & & & & \\
\hline & CS * Competitive intensity & & & $-0.15^{*}$ & -0.13 \\
\hline & CS * Market dynamism & & & & 0.06 \\
\hline & $\begin{array}{l}\mathrm{CM} * \text { Competitive intensity } \\
\mathrm{CM} * \text { Market dynamism }\end{array}$ & & & $\begin{array}{r}-0.08 \\
0.08\end{array}$ & $\begin{array}{r}-0.07 \\
0.08\end{array}$ \\
\hline & Curvilinear effects & & & & \\
\hline & $\mathrm{CS} * \mathrm{CS}$ & & & & $0.21^{* *}$ \\
\hline & $\mathrm{CM} * \mathrm{CM}$ & & & & 0.01 \\
\hline & Control variables & & & & \\
\hline & Competitive intensity & -0.06 & -0.04 & 0.02 & 0.03 \\
\hline & Market dynamism & 0.08 & 0.03 & -0.02 & -0.03 \\
\hline & Venture age & $0.20 * *$ & $0.23^{* * * *}$ & $0.25^{* * * *}$ & $0.26 * * *$ \\
\hline & Venture size & $0.24 * * *$ & $0.23^{* * * *}$ & $0.20 * *$ & $0.17 * *$ \\
\hline & IQ of the founders & $0.25^{* * *}$ & $0.22 * *$ & $0.24^{* *}$ & $0.21 * *$ \\
\hline & $R^{2}(\%)$ & & 22.6 & & \\
\hline & $\Delta R^{2}(\%)$ & $\Delta 17.2^{* * * *}$ & $\Delta 5.4^{* *}$ & $\Delta 2.9$ & $\Delta 3.1$ \\
\hline & $F$ & 3.96 *** & $3.87 * * *$ & $2.77 * * *$ & $2.69 * * *$ \\
\hline Table VI. & $N$ & 101 & 101 & 101 & 101 \\
\hline
\end{tabular}

Regression analysis, technological success

Notes: * Significant at 10 percent; ** significant at 5 percent; *** significant at 1 percent (one sided)

supported), whereas there is again a U-shaped effect of customer orientation $(\beta=0.21$, $p<0.05$, H5c supported). Additionally we found a direct effect of IQ on technological success $(\beta=0.21, p<0.05)$. Technological success seems to increase with the size $(\beta=0.17, p<0.05)$ and the age $(\beta=0.26, p<0.01)$ of software ventures.

\section{Discussion and implications}

There are three major findings in our study: first, the IQ of the founders in new software ventures has considerable and highly significant effects on customer orientation and competitor orientation. Founders should have in mind the importance of good communication, task coordination, mutual support and sharing the right information among each other in order to fulfil successfully the tasks of marketing management. Although this study had a defined focus on customer and competitor orientation, we assume IQ to be an important antecedent for the fulfilment of other tasks in new software venture management, such as product development, procurement and distribution. Further research will have to take a look at these issues in order to provide a comprehensive framework for the role of IQ in new venture management.

The second major finding of our study is the existence of a U-shaped relationship between customer orientation and venture performance. Competitor orientation has a linear, positive and significant effect on technological success. The support for our hypothesis on a curvilinear relationship underlines the ambiguous effects of customer orientation especially and marketing action in general. Software venture founders should consider to which degree they want to implement customer orientation in their company. Our results indicate to maximize customer orientation - or leave it out. In 
either case a "stuck in the middle"-situation should be avoided, as it leads to low levels of venture performance. Future research should deal with the question if there is really no optimal level for customer orientation. In our study, we have taken a look at very young software ventures. As companies become older and larger, resource restrictions might lose their importance and the marginal utility of customer orientation diminishes, which could cause a change from the U-shaped to an inverted U-shaped-relationship.

Third, we found moderating influences of the market environment, i.e. competitive intensity and market dynamism, to be weak. The only strong effect was found for the moderating effect of market dynamism on customer orientation and economic performance. The limited role of market environment and its moderating effects is surprising, although previous studies (e.g. Jaworski and Kohli, 1993) have come to similar results. We presume that specific industry characteristics determine whether market environment affects the customer/competitor-performance relationship or not. Future research may take a closer look into the relationships of customer and competitor orientation on small venture success in other industrial environments as well as service businesses.

\section{References}

Anderson, J.C. and Gerbing, D.W. (1988), "Structural equation modeling in practice: a review and recommended two-step approach”, Psychological Bulletin, Vol. 103 No. 3, pp. 411-23.

Appiah-Adu, K. (1997), "Market orientation and performance: do the findings established in large firms hold in the small business sector?”, Journal of Euro-Marketing, Vol. 6 No. 3, pp. 1-26.

Appiah-Adu, K. and Singh, S. (1998), "Customer orientation and performance: a study of SMEs", Management Decision, Vol. 36 No. 6, pp. 385-94.

Bagozzi, R.P. (1994a), "Measurement in marketing research: basic principles of questionnaire design”, in Bagozzi, R.P. (Ed.), Principles of Marketing Research, Blackwell Publishers, Cambridge, MA.

Bagozzi, R.P. and Yi, Y. (1991), "Multitrait-multimethod matrices in consumer research", Journal of Consumer Research, Vol. 17, pp. 426-39.

Bagozzi, R.P., Yi, Y. and Phillips, L. (1991), "Assessing construct validity in organizational research”, Administrative Science Quarterly, Vol. 36, pp. 421-58.

Balakrishnan, S. (1996), "Benefits of customer and competitive orientations in industrial markets”, Industrial Marketing Management, Vol. 25, pp. 257-69.

Cortina, J.M. (1993), "Interaction, nonlinearity, and multicollinearity: implications for multiple regression”, Journal of Management, Vol. 19, No. 4, pp. 915-22.

Dawes, J. (1999), "The relationship between subjective and objective company performance measures in market orientation research: further empirical evidence", Marketing Bulletin, Vol. 10, pp. 65-75.

Day, G.S. (1994), "The capabilities of market-driven organizations", Journal of Marketing, Vol. 48, October, pp. 37-51.

Day, G.S. and Wensley, R. (1988), “Assessing advantage: a framework for diagnosing competitive superiority”, Journal of Marketing, Vol. 52, April, pp. 1-20.

Deshpandé, R., Farley, J.U. and Webster, F.E.J. (1993), "Corporate culture, customer orientation, and innovativeness in Japanese firms: a quadrad analysis", Journal of Marketing, Vol. 57, January, pp. 23-37.

Ensley, M.D. and Amason, A.C. (1999), Entrepreneurial Team Heterogeneity and the Moderating Effects of Environmental Volatility and Team Tenure on New Venture Performance, Babson College Frontiers of Entrepreneurship Research, Wellesley, MA.

Founder team interaction 
MRN

32,6

552
Fornell, C. and Larcker, D. (1981), "Evaluating structural equation models with unobservable variables and measurement error", Journal of Marketing Research, Vol. 18, pp. 39-50.

Gladstein, D.L. (1984), "Groups in context: a model of task group effectiveness", Administrative Science Quarterly, Vol. 29, pp. 499-517.

Golann, B. (2006), "Achieving growth and responsiveness: process management and market orientation in small firms", Journal of Small Business Management, Vol. 44 No. 3, pp. 369-85.

Gray, B., Matear, S., Boshoff, C. and Matheson, P. (1998), "Developing a better measure of market orientation”, European Journal of Marketing, Vol. 32 Nos. 9-10, pp. 884-903.

Greenley, G.E. (1995), "Market orientation and company performance: empirical evidence from UK companies”, British Journal of Management, Vol. 6, pp. 1-13.

Hackman, J.R. (1987), "The design of work teams", in Lorsch, J.W. (Ed.), Handbook of Organizational Behavior, Prentice-Hall, Englewood Cliffs, NJ.

Han, J.K., Kim, N. and Srivastava, R.K. (1998), "Market orientation and organizational performance: is innovation a missing link?", Journal of Marketing, Vol. 62, October, pp. 30-45.

Helfert, G. and Gemuenden, H.G. (2001), "Relationship marketing teams", in Gemuenden, H.G. and Högl, M. (Eds), Management Von Teams, Gabler, Wiesbaden.

Hills, G.E. and Star, A.D. (1985), Marketing Strategy Elements for New Venture/Early Stage Firms as Perceived by Venture Capitalists - An Exploratory Study, Babson College Frontiers of Entrepreneurship Research, Wellesley, MA.

Homburg, C. and Baumgartner, H. (1995), "Beurteilung von kausalmodellen - Bestandsaufnahme und Anwendungsempfehlungen", Marketing ZFP, Vol. 3, pp. 162-76.

Homburg, C. and Werner, H. (1998), Kundenorientierung mit System - Mit Customer Orientation Management zu profitablen Wachstum, Campus, Frankfurt a M.

Jaworski, B.J. and Kohli, A.K. (1993), "Market orientation: antecedents and consequences", Journal of Marketing, Vol. 57, July, pp. 53-70.

Jöreskog, K.G. and Sörbom, D. (1996), LISREL 8: User's Reference Guide, Scientific Software, Chicago, IL.

Kamm, J.B., Shuman, J.C., Seeger, J.A. and Nurick, A.J. (1990), "Entrepreneurial teams in new venture creation: a research agenda", ET\&P - Entrepreneurship Theory and Practice, Vol. 14 No. 4, pp. 7-18.

Keh, H.T., Nguyen, T.T.M. and Ping Ng, H. (2007), "The effects of entrepreneurial orientation and marketing information on the performance of SMEs", Journal of Business Venturing, Vol. 22 No. 4, pp. 592-611.

Kumar, K., Subramanian, R. and Yauger, C. (1998), "Examining the market orientation performance relationship: a context-specific study”, Journal of Management, Vol. 24 No. 2, pp. 203-33.

Lafferty, B.A. and Hult, G.T.M. (2001), "A synthesis of contemporary market orientation perspectives”, European Journal of Marketing, Vol. 35 Nos. 1-2, pp. 92-109.

Lechler, T. and Gemuenden, H.G. (1999), "Social interaction: a determinant of entrepreneurial team venture success", paper presented at the RENT Conference, London.

Li, T. and Calantone, R.J. (1998), "The impact of market knowledge competence on new product advantage: conceptualization and empirical examination”, Journal of Marketing, Vol. 62, October, pp. 13-29.

Lusch, R.F. and Laczniak, G.R. (1987), "The evolving marketing concept, competitive intensity and organizational performance", Journal of the Academy of Marketing Science, Vol. 15 No. 3, pp.1-11. 
Mellewigt, T. and Späth, J.F. (2001), Occurence, Size, Completeness and Performance of Entrepreneurial Teams: A Meta-analysis of German and US Empirical Studies, Babson College Frontiers of Entrepreneurship Research, Wellesley, MA.

Narver, J.C. and Slater, S.F. (1990), "The effect of a market orientation on business profitability", Journal of Marketing, Vol. 54, October, pp. 20-35.

Pelham, A.M. (1997), "Market orientation and performance: the moderating effects of product and customer differentiation", Journal of Business \& Industrial Marketing, Vol. 12 No. 5, pp. 276-96.

Pelham, A.M. and Wilson, D.T. (1996), "A longitudinal study of the impact of market structure, firm structure, strategy, and market orientation culture on dimensions of small-firm performance", Journal of the Academy of Marketing Science, Vol. 24 No. 1, pp. 27-43.

Pinto, M.B. and Pinto, J.K. (1990), "Project team communication and cross-functional cooperation in new program development”, Journal of Product Innovation Management, Vol. 7, pp. 200-12.

Ruekert, R.W. (1992), "Developing a market orientation: an organizational strategy perspective", International Journal of Research in Marketing, Vol. 9, pp. 225-45.

Salomo, S. (2003), "Customer orientation in innovation projects and new product development success: the moderating effect of product innovativeness", International Journal of Technology Management, Vol. 26 Nos. 5-6, pp. 442-63.

Sheremata, W.A. (2002), "Finding and solving problems in software new product development", Journal of Product Innovation Management, Vol. 19, pp. 144-58.

Slevin, D.P. and Covin, J.G. (1987), "The competitive tactics of entrepreneurial firms in high- and low-technology industries", in Churchill, N.C. (Ed.), Frontiers of Entrepreneurship Research, Babson College, Babson Park, MA.

Taulicar, T., Grundei, J. and v.Werder, A. (2005), "Strategic decision making in start-ups: the effect of top management team organization and processes on speed and comprehensiveness", Journal of Business Venturing, Vol. 20 No. 4, pp. 519-41.

Tjosvold, D. (1995), "Cooperation theory, contrcutive controvery, and effectiveness: learning from crisis", in Guzzo, R.A. and Salas, E.A.A. (Eds), Team Effectiveness and Decision Making in Organizations, Jossey-Bass, San Francisco, CA.

Walsh, S. and Kirchhoff, B.A. (2001), Entrepreneur's Opportunities in Technology Based Markets, USASBE - United States Association for Small Business and Entrepreneurship, Orlando, FL.

Watson, W.E., Ponthieu, L.D. and Critelli, J.W. (1995), "Team interpersonal process effectiveness in venture partnerships and its connection to perceived success", Journal of Business Venturing, Vol. 10 No. 5, pp. 393-412.

Zeithaml, V.A. (1988), "Consumer perceptions of price, quality, and value: a means-end model and synthesis of evidence", Journal of Marketing, Vol. 52, July, pp. 2-22.

\section{Further reading}

Högl, M. and Gemuenden, H.G. (2001), "Teamwork quality and the success of innovative projects: a theoretical concept and empirical evidence", Organization Science, Vol. 12 No. 4, pp. 435-49.

Sapienza, H.J. (1991), "Comets and duds: characteristics distinguishing high and low performing high potential ventures", in Churchill, N.C. (Ed.), Frontiers of Entrepreneurship Research, Babson College, Babson Park, MA.

\section{About the authors}

Thilo A. Mueller (Dr) is Product Marketing Director at Robert Bosch GmbH's division Gasoline Systems. Before, he was an assistant professor for Technology and Innovation Management of the Berlin University of Technology. He has studied industrial engineering at the University of

Founder team interaction

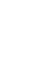


MRN

32,6

554
Karlsruhe and published articles in international journals and on international conferences on entrepreneurship and industrial marketing research. Thilo A. Mueller is the corresponding author and can be contacted at: thilo.a.mueller@gmx.de

Hans Georg Gemünden (Prof. Dr. rer. oec. habil.) has the Chair for Technology and Innovation Management of the Berlin University of Technology. He received his diploma and doctoral degree at the University of Saarbruecken, his habilitation degree at the University of Kiel. He has published several books and numerous articles in the fields of innovation and technology management, project management, entrepreneurship, marketing, business policy and strategy, human information behavior and accounting.

To purchase reprints of this article please e-mail: reprints@emeraldinsight.com Or visit our web site for further details: www.emeraldinsight.com/reprints 